\title{
The Use of Digital Comic in Developing Student's English Competence
}

\author{
Finaty Ahsanah ${ }^{1}$, Dias Tiara Putri Utomo ${ }^{2}$ \\ 1finatyahsanah@umla.ac.id \\ 2Diastiara@umla.ac.id \\ 1,2Faculty of Health, Universitas Muhammadiyah Lamongan, East Java, Indonesia
}

Received: 31 October 2020 Accepted: 21 November 2020

DOI: $10.24256 /$ ideas.v8i2.1660

\begin{abstract}
This current study is aimed to know whether any improvement or not in using digital comic as the media on student's English competence. The researchers used quantitative approach with pre-experimental design. This research was conducted at Universitas Muhammadiyah Lamongan and the sample was 42 pharmacist medical students. The instrument that was used to measure students' English competence was Test of English as Foreign Language (TOEFL). The result of the test was analyzed by using statistical analysis of paired sample t-test. The finding showed that there was significant improvement before and after the treatment, it can be proved by the significant value of the pre and post test which was 0.000 ( 2 tailed). Since the significance value (2-tailed) was less than 0.05 , it means that the hypotheses of this study was accepted. In other words, the students positively received the use of digital comic for English learning activity. Therefore, digital comic can be assumed as an effective media or tool for enhancing students' English competence.
\end{abstract}

Keywords: English Competence, Digital comic, Pre-Experimental, Test of English as Foreign Language

\section{Introduction}

English competence is undoubtedly important nowadays due to the fact that it is used as an international language; hence many universities in non-English speaking country strive to give its best in facilitating the students to have good English competence. By having good English competence, it will broaden the opportunity of getting various kind of job all over the globe. There are several instruments that usually used to measure English competence, yet one of the most 
well-known instruments is Test of English as Foreign Language or commonly known as TOEFL (Handayani, 2019 \& Tangkelangi, 2020). Obtaining high scores in TOEFL can be considered as having an outstanding English competence.

In Indonesia, the phenomenon of this issue cannot be denied. Therefore, it leads a number of universities in Indonesia to give TOEFL-preparation class to all students in every department in order to help them gaining high TOEFL scores. However, learning English is not an easy thing especially learning TOEFL. The statements are in line with the previous research conducted by Mahmud (2014), he stated that the students faced difficulties in answering the TOEFL test, especially deals with structure and written expression. In 2018, Hajri, Jufrizal, \& Wahyuni investigated the students of Universitas Negeri Padang related to their difficulties in paper-based TOEFL focusing on structure and written expression. They explored that the students had some difficulties in answering the structure and written expression, they found out that the most difficult items were negation, reduced-form and parallel structure. These previous studies proved many students or language learners face difficulties in learning English especially when it deals with the standardized test like TOEFL.

Another research conducted by couple of colleagues (Tilana, Yunita, \& Zahrida, 2019), they investigated students' English structure and written competence. The subject of this research was the $6^{\text {th }}$ semester students of the English study program, at Universitas Bengkulu. They used TOEFL and interview as the instrument of the research. They reported that the majority of the students' English competence was poor, they also revealed that grammar section was the most difficult part and they added there were four factors influenced students difficulties, poor understanding of grammar, less focus, lack of practice and limited vocabulary. This study strengthen the fact that students need to be assist in learning English in order to help them increasing their English competence.

Considering all the previous issues stated above, it is getting worse with the pandemic covid-19 that has spread for the past several months in Indonesia. The Coronavirus hampered all of the educational activities. During the pandemic all of the teaching and learning activities are doing online (Windhiyana, 2020). Furthermore, Rosali (2020) investigated the impact of Covid-19 on the educational system and the result of the study showed that during the Covid-19 pandemic in the education department uses an online model with applications such as: Google meet, Zoom, Whatsapp, Telegram, Google Classroom, Youtube, Facebook, and Messenger. She added it needs more varied model in order to keep it interesting if used in the long run. The Pandemic Covid-19 is the cause of every chaos in educational system.

This current situation makes the students face the difficulties in learning English even more. An interesting media needs to be applied in order to help them receive all the materials effectively. At this point, the teacher is asked to use an effective media for assisting the students so that they can acquire all the materials without any problems. The media or tool that is used for online teaching activity 
should be interesting and fun. It has to make students feel enjoy while getting all the materials they needed. In fact, there are so many medias that can be used in online teaching, digital comic can be one of the alternatives media to use.

According to Darmawan (2010) using comic strip was more effective in developing student's ability in writing. The next following years a research conducted by Savora (2012) stated that using comic strip recount text more effective to improve student's writing ability. In 2016, Suwastomo (2016) reported that comic was a good media in improving students vocabulary. He stated that the students' reading skills improved after the implementation of comic strips to the class. The other studies conducted by Anni Widiyanti (2018) and Solano (2018), the studies conducted by them was related to the use of Digital comic in Engish Foreign Language classroom and the result of their studies found out that Digital comic was very good media to use in helping the students learn English (Solano et al., 2018).

Therefore, based on the background of the study, the researchers are inspired to explore the use of digital comic in another focus of language learning. Most of the studies that previously conducted was focusing on the implementation of comic strips or digital comic on students' writing and reading skills. However, this current study is going to be more into the TOEFL learning process. There are three sections of the TOEFL test, the first is Listening Comprehension, the second one is Structure and Written Expression and the last is Reading Comprehension. Hence, this current study explores all those three sections of TOEFL. There two questions that have been formulated in this study. The first one is whether digital comic an effective media in developing students' English competence. Second, whether any significant difference before and after implementing digital comic into TOEFL preparation classroom.

Afterwards, there are some research objectives. First is to find out whether digital comic can be proven as an effective tool or not on developing students' English competence. The last is to figure out the significant difference before and after implementing the treatment.

\section{Method}

The research design that is used in this study was quantitative approach with pre-experimental design. Quantitative research is explaining phenomena by collecting numerical data that are analyzed using mathematically based methods in particular statistic (Muijs, 2011). In quantitative research, the researchers collect numerical data and this is closely connected to the definition of analysis using mathematically methods. In this current study, the researchers collected the numerical data by using pre-experimental design. There are three stages of conducting pre-experimental design:

Figure 1. Stages of Pre-Experimental Design

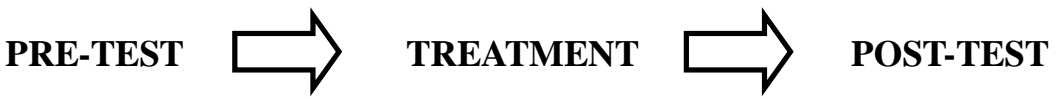


The figure 1 showed the steps in conducting a pre-experimental design. The first one is gathering the data by administering the pre-test to the sample of the study. After the pre-test being administered, the samples are given the treatment in this case is implementing the digital comic. This treatment was done in 14 meetings, the brief explanation of the treatment implementation can be seen at Discussion part. Finally, the last step was doing the post-test to obtain the final data for the study.

The study was conducted at Universitas Muhammadiyah Lamongan, East Java, Indonesia. The population of this study was all of the fourth and sixth semester students who got the TOEFL-preparation test or it was around 296. Then, the sample of this study was obtained by purposive sampling of 42 pharmacist medical students who were on their fourth semester. The instrument of the study was TOEFL and interview. The numerical data was obtained by pre-test and post-test that was collected by Test of English as Foreign Language (TOEFL) scores. Then, the interview was used as the supporting data which was used to strengthen the findings of the study.

\section{Results}

The result of this current study consisted of the data distribution and statistical analyses. Before going further to look at the use of Digital comic on developing students' English competence; the normality of the data was checked. It is as followed:

Table 1. Normal Distribution Pre and Post Test

\begin{tabular}{|l|r|r|r|r|r|r|}
\hline \multicolumn{1}{|c|}{ Tests of Normality } \\
\cline { 2 - 7 } & \multicolumn{2}{|c|}{ Kolmogorov-Smirnov ${ }^{\text {a }}$} & \multicolumn{3}{c|}{ Shapiro-Wilk } \\
\cline { 2 - 7 } & Statistic & \multicolumn{1}{c|}{ df } & \multicolumn{1}{c|}{ Sig. } & Statistic & \multicolumn{1}{c|}{ df } & \multicolumn{1}{c|}{ Sig. } \\
\hline PRE TEST & .111 & 42 & $.200^{\prime}$ & .935 & 42 & .019 \\
POST TEST & .142 & 42 & .034 & .966 & 42 & .238 \\
\hline
\end{tabular}
*. This is a lower bound of the true significance.
a. Lilliefors Significance Correction

Table 1 showed that the data of pre and post test is normally distributed by the significant value of .019 for pre-test and .238 for post-test by looking at the Shapiro-Wilk. Both of the significant value of the data was greater than $p .05$, it means that the data is perfectly met the assumption of normal distribution. Therefore, the paired sample t-test can be applied to gain the final results.

Table 2. The Description of the Statistical Data

\begin{tabular}{|c|c|c|c|c|c|}
\hline \multicolumn{6}{|c|}{ Paired Samples Statistics } \\
\hline & & Mean & $\mathrm{N}$ & Std. Deviation & $\begin{array}{l}\text { Std. Error } \\
\text { Mean }\end{array}$ \\
\hline \multirow[t]{2}{*}{ Pair 1} & PRE TEST & 350.64 & 42 & 16.417 & 2.533 \\
\hline & POST TEST & 375.40 & 42 & 30.506 & 4.707 \\
\hline
\end{tabular}

In answering the first research question, it can be seen in table 2 . The 
previous table is the statistical description of the pre and post test of the group who had got the treatment. It showed that the mean of the pre-test was 350.64, the standard deviation was 16.417 and the standard error mean was 2.5333 , while the mean for post-test was 357.40, the standard deviation was 30.506 and standard error mean was 4.707. Therefore, based on the table above, it can be said that there was an improvement in students' English competence after and before the treatment. In other words, digital comic can be assumed as an effective media to enhance students' English competence.

Furthermore, in order to answer the second research questions, the paired sample test should be applied. The result of paired sample test is in the following table:

Table 3. Paired Sample Test

\begin{tabular}{|c|c|c|c|c|c|c|c|c|}
\hline \multicolumn{9}{|c|}{ Paired Samples Test } \\
\hline & \multicolumn{5}{|c|}{ Paired Differences } & \multirow[b]{3}{*}{$t$} & \multirow[b]{3}{*}{ df } & \multirow[b]{3}{*}{ Sig. (2-tailed) } \\
\hline & \multirow[b]{2}{*}{ Mean } & \multirow[b]{2}{*}{ Std. Deviation } & \multirow{2}{*}{$\begin{array}{l}\text { Std. Error } \\
\text { Mean }\end{array}$} & \multicolumn{2}{|c|}{$\begin{array}{l}95 \% \text { Confidence Interval of the } \\
\text { Difference }\end{array}$} & & & \\
\hline & & & & Lower & Upper & & & \\
\hline PRE TEST - POST TEST & -24.762 & 29.192 & 4.504 & -33.858 & -15.665 & -5.497 & 41 & .000 \\
\hline
\end{tabular}

To answer the last research question, whether there is a significant difference before and after implementing the digital comic, the result of paired sample test showed the mean differences of pre-test and post-test. It was 24.762, standard deviation was 29.192, standard error mean was 4.504 and t-obtained was 5.497. The significant value of pre-post test was $.000<0.05$. It means, the significant value was lower than $p$. value of 0.05 . In other words, there was a significant difference of students' English competence before and after getting digital comic as the media for the treatment. Therefore, it can be concluded that the students' got improvement in their English competence after the implementation of digital comic.

\section{Discussion}

This research was conducting in TOEFL-preparation classroom. As stated in the previous section that this study was at Universitas Muhammadiyah Lamongan or well-known as (UMLA). UMLA is one of the biggest Universities in Lamongan, East Java. Due to the fact that English becomes an important factor in this globalization era, UMLA also took step ahead in preparing the students to have a good English competence. Therefore, there is a TOEFL preparation class for all the students who on the last year of the study. They were given all the materials of TOEFL including listening comprehension, structure and written expression and also reading comprehension. The following part is the brief description of the process of conducting the digital comic into a TOEFL preparation classroom.

Digital comic is an effective media in developing students' English competence.

As it can be seen from the result of this current research that digital comic is 
an effective media in developing students' English competence. Digital comic was aimed to assist the students' enhancing their English competence. In implementing the digital comic, the researchers conducting these several steps. First, before implementing digital comic, the students were given the pre-test. The pre-test was obtained from TOEFL (as it is mentioned previously) and it was used in order to know their English competence. The test was consisted of 140 questions: 50 questions of Listening Comprehension, 40 questions of Structure and Written expression, and 50 questions of Reading Comprehension. The students must complete all the questions of the test within approximately 120 minutes. After the researchers got the students' scores of pre-test, the researchers found out that the students had some weaknesses on answering the test and they really needed to be assisted to enhance their English competence. A week after the test was done; the students were given the TOEFL preparation class. The TOEFL preparation class was held 2 weeks before the quarantine was announced. Before the quarantine, the class was done face to face. Yet, after the quarantine was announced all the teaching and learning activity was done online. For the first two meetings, the researchers noticed that most of the students had difficulties in absorbing all the materials. The first two meetings were done in a conventional way.

After doing the pre-test and having face to face meetings twice, the researchers gave treatment to the students. In this part, the researcher explained briefly the usage of the digital comic in TOEFL-preparation class. There were 16 meetings of TOEFL preparation class and it was divided into some sections. The first section was the pre-test that has been previously discussed. Then, six meetings were for structure and written expression section. Three meetings were for listening comprehension section and three meetings were for reading comprehension section. Then, the last meeting was for administering the post-test. Structure and written expression had more meetings than other sections due to the fact that it was more complicated than the other sections for the students. Furthermore, the following part is going to discuss about the procedures of implementing the digital comic in TOEFL preparation classroom.

The first procedure was the researchers had the TOEFL-preparation class online. At the beginning of the class, the researchers explained the basic purpose of using digital comic and also explained all about digital comic. After explaining about digital comic, the researchers sent the digital comic through Edmodo platform. The digital comic that was sent to the students was made by using Pixton website application. The first digital comic focused on Structure and Written Expression and it was about the subject and verb agreement. Then, the researchers gave the students couple of minutes to understand all the words written in the comic. The next step was discussion session related to the comic that has been sent to the students, students were freely to share their opinions and thoughts about the topics. The researchers also added some exercises related to the topics. After the discussion session done, the researchers gave couple of minutes for the students to answer the questions after that the researchers asked the students to 
type their answer on the Edmodo Application. Whatsapp was also used to be an additional online media when there was a misconception of the topics; usually the researchers sent the brief explanation by sending a voice note.

The next meeting, the students were still given another topic of Structure and Written Expression. This time, the topic was about adjectives and adverbs. The researchers tried so hard to make an interesting digital comic related to the topic. Since, the researchers wanted to make the students understand all the materials easily. In this meeting, the researchers gave the students more time to absorb the digital comic given. The process of this kind of activity was done up to 14 meetings, with the same procedures that was giving the digital comic, asking the students to read and understand the comic given, giving the students times to ask the things they did not understand, handing them exercises the related to the topics and the final activity of every meeting was discussion about the exercises. In the last meeting, the students were doing the post test. The post-test was administered in order to find out the students' improvement.

Related to the use of the digital comic as the media for teaching and learning activity, the students were being interviewed about it. Some of the students had a very good response related to the digital comic that was given to them. They said digital comic was very interesting and they found themselves enjoy learning English using it. Some of them stated that they did not even notice that time flied really fast when they learnt using digital comic. Those statements were in line with the answers of all the exercises given to them. Most of them answered correctly, yet there were some of them still faced some difficulties. For the example in subject and verb agreement topic, they had difficulties in differentiate the use of verb with (e/es). Most of them were confused with the use of verb with (s/es), they thought the verb with s/es was plural verb, so they tended to choose plural subject to be matched with the verb (e/es). Or like in adjectives and adverbs topic, the students had difficulties in using the adjectives and adverbs. They supposed to use adjectives after linking verb (LV), yet they tend to use adverbs instead of adjectives. In the end of the meeting, the researchers tried to explain all the misconception of the materials. The following figure is the example of the digital comic about how to use "s/es" in simple present tense.

Figure 2. The example of Digital Comic

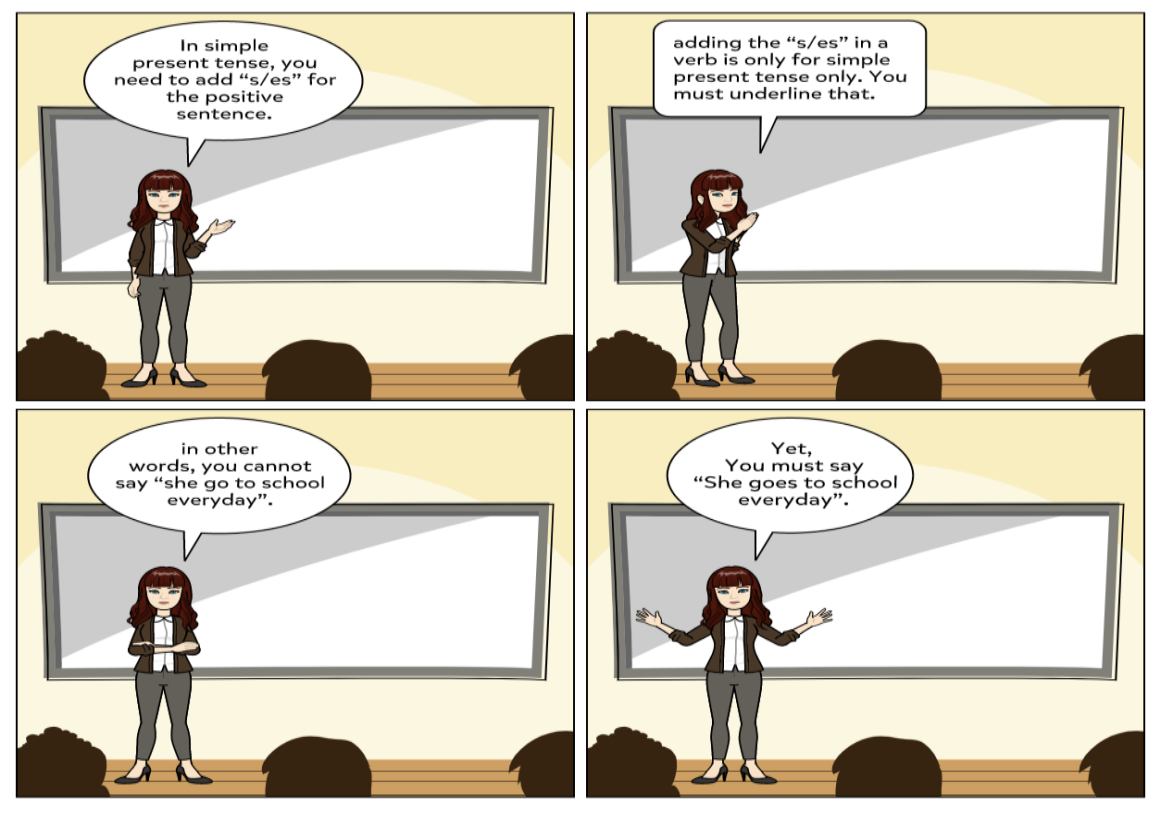


Figure 3. The example of Digital Comic

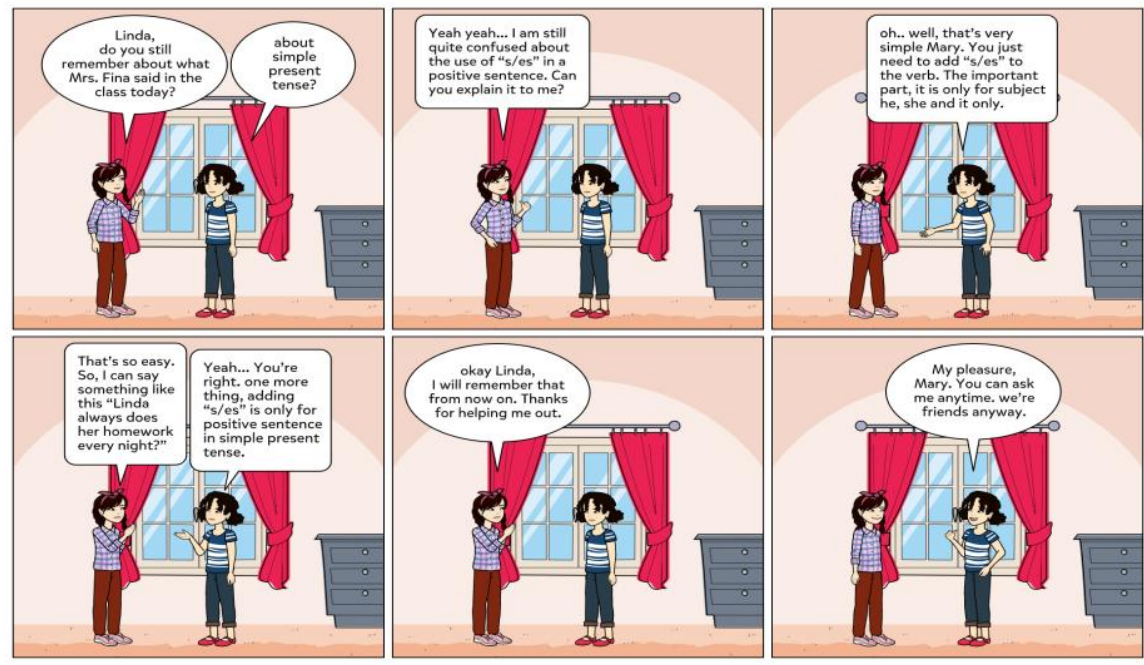

Figure 2 and 3 are the examples of digital comic that discussed the use of 's/es' in simple present tense. The comic was made by using Pixton, it has various kind of background and characters so that it will help the educators to create an interesting comic. As it can be seen, using digital comic was quite interesting because it was involved various pictures. Hence, the students found themselves enjoyed learning English using it. All the statements and findings in this current study was in line with the previous research conducted by Suwastomo (2016), he stated that comic strips was very good media to improve students' English vocabularies. His research was conducted at SMAN 1 Muntok with 55 tenth grade students as samples; he investigated the use of comic as media to enhance students' vocabulary mastery and the result of the independent samples T-test showed that p-output was 0.000 for sig. ( 2 tailed), it can be concluded that there was a significant difference in reading achievement between students' who is taught by comic as a media and those who are not.

Furthermore, this current study was also similar with the other studies conducted by some colleagues who found out the beneficial of using digital comic in English Foreign Language classroom. In 2018, Anni Widiyanti conducted an experimental research on the Islamic web comics as visual aid In teaching English for Islamic secondary school students and the result showed that Islamic Web Comics as visual aid was more effective in teaching English especially reading comprehensions than animated video presentation. In the same year, another study was conducted at a public high school in the southern region of Ecuador (Solano et al., 2018). They investigated the impact of using Pixton for teaching grammar and vocabulary in the EFL Ecuadorian context and the result of the study indicated that Pixton was an effective teaching tool that motivates students to learn grammar and vocabulary in an enjoyable way; they added that the statements can be proved by the students' post test scores which showed a significant 
improvement. It can be assumed, all the previous findings about the use of comic in the EFL classroom indicated that comic can be one of the effective tools in assisting students to learn English effectively.

The studies explained above strengthened this current result of this study. Despite the difficulties of the students when they learn English, digital comic gave them a hope in increasing their English competence. Based on the result of the previous studies and also this current study, it can be concluded that digital comic had big impact in helping the students develop their English competence. Therefore, digital comic can be assumed as an effective media or tool to assist the students in learning English and enhance their English competence.

\section{Conclusion}

The conclusion of this study is that digital comic can be categorized as one of an effective media that may help the students in learning English. Since, the statistical analyses reported that there was a significant difference before and after the students got the treatment. Before the treatment almost all of the students got very low TOEFL scores and then after the treatment was being implemented the students' TOEFL scores was increasing. Therefore, it can be said that digital comic may give a positive feedbacks in English language teaching and learning activities.

In Addition, some suggestions are proposed; for the teachers, the finding of this study is expected to be able to improve the knowledge about digital comic in language teaching and learning activities. Therefore, it is suggested for the teachers to consider using digital comic as the media in learning English. The next is for the future researchers, the current study is explored the use of digital comic on English competence of the students so that it would be interesting to conduct further studies related to the use of digital comic yet by having another focus. The last, the researchers want to state the limitation of the study: this current study is restricted to the use of digital comic in developing students' English competence at Universitas Muhammadiyah Lamongan. Therefore, different findings may be found if this kind of treatment is being implemented to another level of students at another place.

\section{Acknowledgement}

First of all, we would like to say Alhamdulillah to Allah SWT for his blessing and guidance in completing this research. We also would like to express our gratitude to all the colleagues in Universitas Muhammadiyah Lamongan for supporting us in conducting this research. Last but not least, we would like to express our big grateful to all the parties that cannot be all mentioned here, thank you for the love and support. 


\section{References}

Anni, W. M. (2018). Islamic Web Comics as Visual Aid in Teaching English for Islamic secondary school students. Indonesian Journal of Islamic Literature $\begin{array}{llll}\text { and } & \text { Muslim } & \text { Society, } & \text { 75-90. }\end{array}$ https://doi.org/10.22515/islimus.v3i1.1298

Darmawan, R. (2010). The Use of Comic Strips in Improving Student's Reading Comprehension of Narrative Text: A Quasi-Experimental Reasearch in Eight Grade students of SMP 4 Bandung in Academic year 2010/2012. Universitas Pendidikan Indonesia.

Hajri, T., J, \& Wahyuni, D. (2018). An Analysis of Difficulties in Answering Structure and Written Expression of Toefl Made by English. Journal of English Language Teaching, 7(1).

Handayani, F. (2019). Structure and Written Expression Section on Paper-Based TOEFL : Perceived Difficulties by Nursing Students of Poltekes Solok, West Sumatera. Jurnal Educative: Journal of Educational Studies, 4(2).

Mahmud, M. (2014). The EFL Students' Problems in Answering the Test of English as a Foreign Language (TOEFL): A Study in Indonesian Context. Theory and Practice in Language Studies, 4(12), 2581-2587.

Muijs, D. (2011). Doing Quantitative Research in Education with SPSS (Second). https://doi.org/https://dx.doi.org/10.4135/9781849203241

Masruddin, M, Karmila, K. (2018). Constructing WH-Questions througn An Error Analysis at Junior High School of Indonesia. Langkawi: Journal of The Association for Arabic and English 4 (2), 123-137. DOI: http://dx.doi.org/10.31332/lkw.v4i2.852

Rosali, E. S. (2020). Aktifitas Pembelajaran Daring Pada Masa Pandemi Covid-19 Di Jurusan Pendidikan Geografi Universitas Siliwangi Tasikmalaya. Geography Science Education Journal (GEOSEE), 1, 21-30.

Savora, A. (2012). Using Comic Strip Recount Writing to Improve the Ability of Graders in SMP 21 Malang in Academic 2012/2013 Malang. Universitas Malang.

Solano, P. C., Cuesta, L. C., Gonzales, P., Quinones, A., \& Ochoa, C. (2018). the Impact of Using Pixton for Teaching Grammar and Vocabulary. Teaching English with Technology, 18(1), 53-76.

Suwastomo, B. (2016). Teaching Using Comic as a Media to Improve Student's Vocabulary Mastery at Tenth Grade of SMAN 1 Muntok. Studia, 1(1), 1-22.

Tangkelangi, N. I. (2020). Students' Competence in the TOEFL Structure and Written Expression. IDEAS: Journal on English Language Teaching and Learning, Linguistics and Literature, 8(1), 59-66. 
Tilana, P. E., Yunita, W., \& Zahrida. (2019). Students' English Structure and Written Competence. Journal of English Education and Teaching, 3(2), 180-194.

Wahibah, W. (2016). The Effectiveness of Using Pictured Story to Upgrade Students Vocabulary. IDEAS: Journal on English Language Teaching and Learning, Linguistics and Literature, 4(1). doi:https://doi.org/10.24256/ideas.v4i1.179

Windhiyana, E. (2020). Dampak Covid-19 Terhadap Kegiatan Pembelajaran Online Di Perguruan Tinggi Kristen Di Indonesia. Perspektif Ilmu Pendidikan, 34(1), 1-8. https://doi.org/10.21009/pip.341.1 